\title{
SEM (EDX) is an indispensable tool for the characterization of subcutaneous, preperitoneal and visceral adipose tissue of obese patients
}

\author{
Ramūnas Skaudžius ${ }^{1}$, \\ Martynas Misevičius ${ }^{1}$, \\ Vilma Brimiené $\dot{ }^{2}$, \\ Margarita Beniušé $\dot{e}^{3}$ \\ Gintautas Brimas ${ }^{4}$, \\ Aivaras Kareiva $^{1^{*}}$ \\ ${ }^{1}$ Institute of Chemistry, \\ Vilnius University, \\ Naugarduko St. 24, \\ 03225 Vilnius, Lithuania \\ ${ }^{2}$ Clinic of Gastroenterology, \\ Nephrourology and Surgery, \\ Faculty of Medicine, \\ Center of Abdominal Surgery, \\ Vilnius University, Santariškiu St. 2, \\ 08661 Vilnius, Lithuania \\ ${ }^{3}$ Faculty of Mathematics and Informatics, \\ Vilnius University, Naugarduko St. 24, \\ 03225 Vilnius, Lithuania \\ ${ }^{4}$ Clinic of Gastroenterology, \\ Nephrourology and Surgery, \\ Department of General Surgery, \\ Vilnius University, Šiltnamių St. 29, \\ 04130 Vilnius, Lithuania
}

In this work the scanning electron microscopy (SEM) and energy dispersive $\mathrm{X}$-ray (EDX) elemental analysis were used for the characterization of adipose tissue samples taken from volunteer obese patients. The adipose tissue was taken from subcutaneous, preperitoneal and visceral layers of the adipose tissue. The obtained results provided information about the structural composition of adipose tissue layers in the human body, as well as the main microstructural features. It was demonstrated for the first time, to the best of our knowledge, that SEM and EDX are indispensable tools in order to investigate some special morphological features and the elemental composition of different layers of the human adipose tissue, identifying the surface microstructure and its qualitative composition. From the obtained results we concluded that such characterization of the adipose tissue is an essential step for the possible prediction of symptoms of different diseases.

Keywords: adipose tissue, subcutaneous, preperitoneal and visceral layers, obese patients, SEM, EDX

*Corresponding author. Email: aivaras.kareiva@chf.vu.lt 


\section{INTRODUCTION}

The adipose tissue is generally considered as a storage depot for excess energy. The adipose tissue stores energy in the form of lipids and controls the lipid mobilization and distribution in the body. It was considered for a long time that the adipose is a passive organ, but recently the adipose tissue has been described as an endocrine organ with important physiological roles [1, 22. For example, pericardial adipose tissue volumes were significantly increased and the adrenal gland volume was slightly enlarged in patients with chronic major depressive disorder [3]. The recent study described bone marrow fat changes in diabetes and discussed the potential role of marrow fat in skeletal fragility and epigenetic modifications in the adipose tissue and their association with obesity and diabetes 㭌, 印. Obesity is increasingly recognized as a growing cause of cancer risk [6]. The authors in [⿰] concluded that the presence of dyslipidaemia and compromised metabolic health in both lean and obese individuals suggests that the obesity does not represent a main independent risk factor for the development of dyslipidaemia.

There is conflicting information about differences between the fatty acid composition of the subcutaneous adipose tissue (SAT), preperitoneal adipose tissue (PAT) and visceral adipose tissue (VAT). The subcutaneous adipose tissue is the fat just under the skin. The preperitoneal adipose tissue is located prior to the peritoneum. The visceral adipose tissue surrounds organs and interferes the function of the organ. Varying proportions of fatty acids from the adipose tissue may be related to atherosclerosis, metabolic syndrome, type 2 diabetes mellitus, cardiovascular and other diseases and might exert a direct influence on serum lipids that may differ depending on the adipose tissue region [8-12]. During cancer development, loss of the total adipose tissue occurs in most cancer patients [13]. However, the loss of the total adipose tissue did not reflect changes in SAT and VAT in the same direction or intensity. The intensity of SAT is more likely to be gained further way from death, whereas the VAT loss remains constant throughout the disease progression. The adipose tissue distribution during pregnancy showed a tendency towards a decreased accumulation of the subcutaneous and an increased accumulation of the preperitoneal adipose tissue [14]. It was also concluded that PAT may be related to arterial stiffness [15]. The hypothesis that the ratio of the visceral to the subcutaneous adipose tissue is associated with altered sepsis outcome has been recently partially proved [16]. The relationship between the VAT and sugarsweetened beverage intake was also determined [17]. Several studies showed the strongest correlation between symptoms of different diseases and changes in the VAT mass [18-20].

The conventional methods for determining the composition of fats are gas and liquid chromatography [21-25]. However, it is clear that new alternative analytical procedures for the analysis of the adipose are very much desired [26-32]. Although the development of obesity is easily attributed to an excess intake of calories, the underlying reasons for the metabolic disturbances and health risks associated with obesity are still unclear. In this work adipose samples were taken from volunteer obese patients and analysed using scanning electron microscopy (SEM). Also, the aim of the present study was to investigate the distribution of different morphological features in different layers of the adipose tissue from obese patients.

\section{EXPERIMENTAL}

All subjects included in our study were recruited from 35 volunteer patients at the Vilnius University Hospitals' Department of General Surgery where they had been referred for obesity surgery. Men and women aged 18-65 years with a BMI more than $30 \mathrm{~kg} / \mathrm{m}^{2}$ were enrolled in the study. During the laparoscopic gastric banding surgery three samples of the adipose tissue were taken: subcutaneous (SAT), preperitoneal (PAT) and visceral (VAT) (see Fig. 1). The study

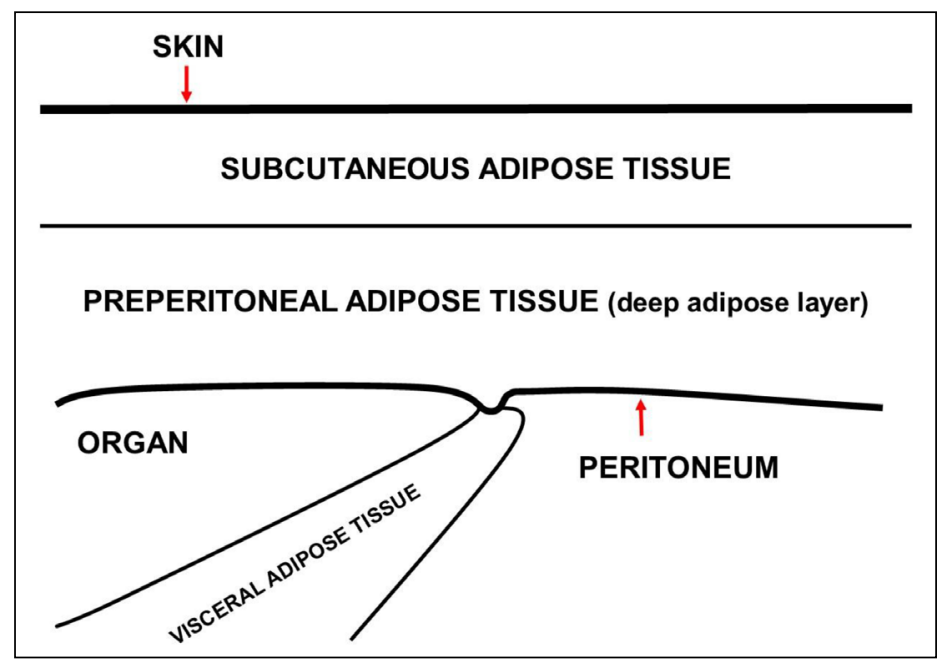

Fig. 1. A schematic diagram of adipose tissues in the human body 
protocol was approved by the Lithuanian Bioethics Committee, with the aim and design of the study explained to each subject, who in turn gave their informed consent. The adipose tissue samples ( $5 \mathrm{~g}$ from each region) were washed out in a normal saline solution and frozen immediately. The adipose tissue samples were stored in $-70^{\circ} \mathrm{C}$ temperature before the microscopical analysis was performed. For the morphological characterization of the adipose tissue specimens a scanning electron microscope (SEM) Hitachi SU-70 was used. The energy dispersive X-ray (EDX) elemental analysis was performed with a Hitachi Tabletop Microscope TM3000.

\section{RESULTS AND DISCUSSION}

The scanning electron micrographs of the adipose tissue obtained from different layers of obese patients, randomly selected but without metabolic diseases, are shown in Fig. 2 indicating the surface similarity and difference of specimens. The main morphological features of the adipose tissue taken from the adipose tissue layers SAT, PAT and VAT of individual patients are quite similar. The microstructure of the sample obtained from the adipose tissue layers SAT, PAT and VAT is characterized by a number of planar particles $1-1.5 \mu \mathrm{m}$ in size. The adipose material shows a rather open structure and a large surface area with no microscopic evidence for the existence of pores or interparticle voids. However, some rod- and/or stick-like individual particles $0.5-1.0 \mu \mathrm{m}$ in size could also be seen in the SAT layer. Very small $(50-100 \mathrm{~nm})$ spherical particles are located on the surface of planar particles of the adipose tissue in the VAT layer. However, the microstructure of the adipose tissue taken from the preperitoneal (PAT) layer does not show any specific features.

The scanning electron micrographs of the adipose tissue were also obtained from different layers of obese patients with metabolic diseases who were randomly selected. Figure 3 shows the representative SEM micrographs of the PAT layer of adipose tissue samples taken from obese patients having different metabolic diseases (diabetes, galactosemia, hepatitis and other). No progressive changes in the morphology of the PAT samples in comparison with the sample from healthy patients were observed. The SEM micrographs of these samples show that the adipose tissue of the preperitoneal layer is composed of irregularly shaped particles $200 \mathrm{~nm}-2 \mu \mathrm{m}$ in size which are closely connected to each other forming hard agglomerates. The existence of a continuous network of particles is evident. Some parts of the samples are composed of bigger particles, some contain significantly smaller particles. However, the microstructure of the adipose tissue PAT layers obtained from 35 patients is quite similar. The morphology of most PAT samples consisted of similar particulate matter. Only very seldom some additional small nanoscaled separate particles could be seen on the surface of the adipose tissue of these speci-
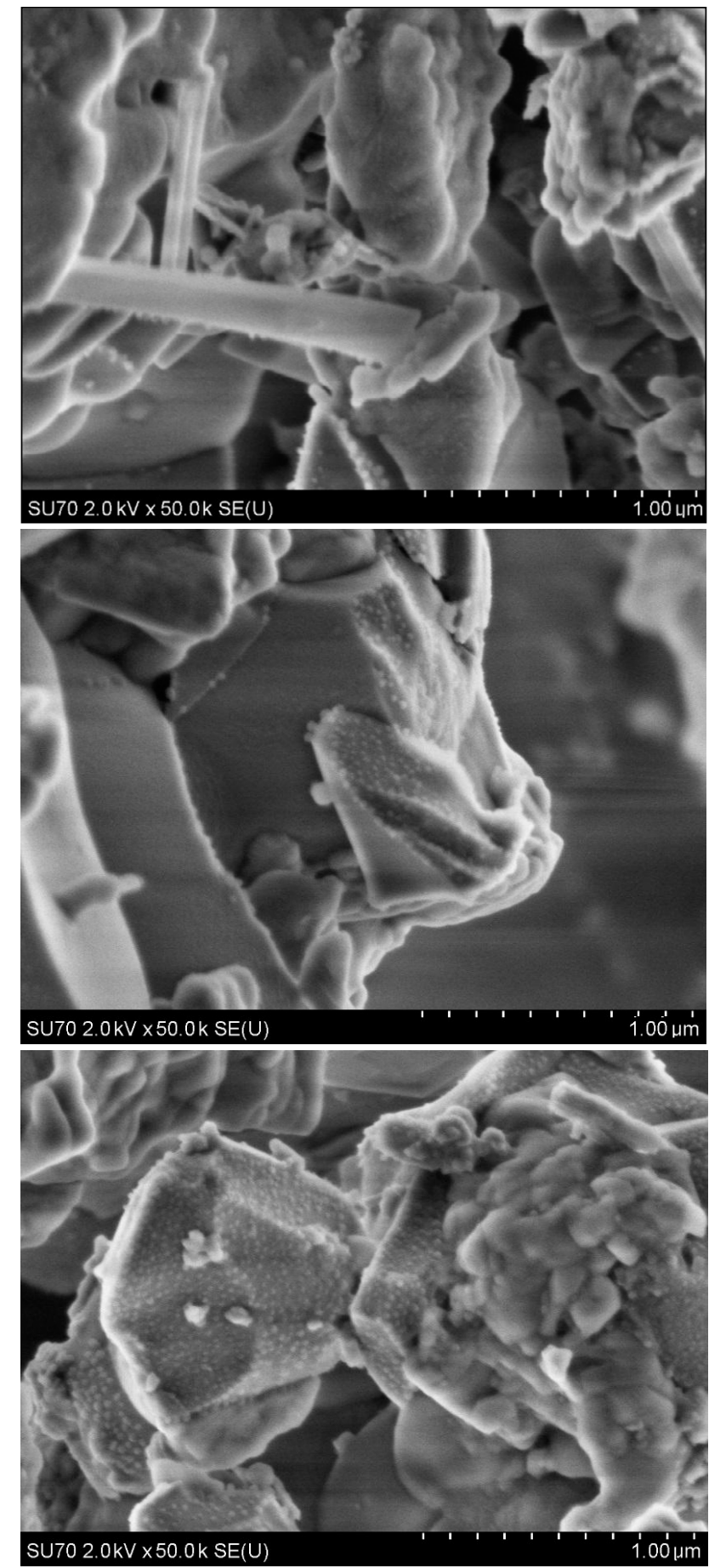

Fig. 2. SEM micrographs of the adipose tissue obtained from subcutaneous (top), preperitoneal (middle) and visceral (bottom) layers of obese healthy patients

mens. These initial SEM observations let us to conclude that the preperitoneal layer perhaps could be considered as a passive organ, i.e. is not associated with metabolic changes in the human body.

The SEM micrographs of the subcutaneous adipose tissue layer taken from obese patients having different metabolic diseases are presented in Fig. A. These SEM images are slightly different in comparison with ones taken from the SAT layers of people without metabolic diseases. It 

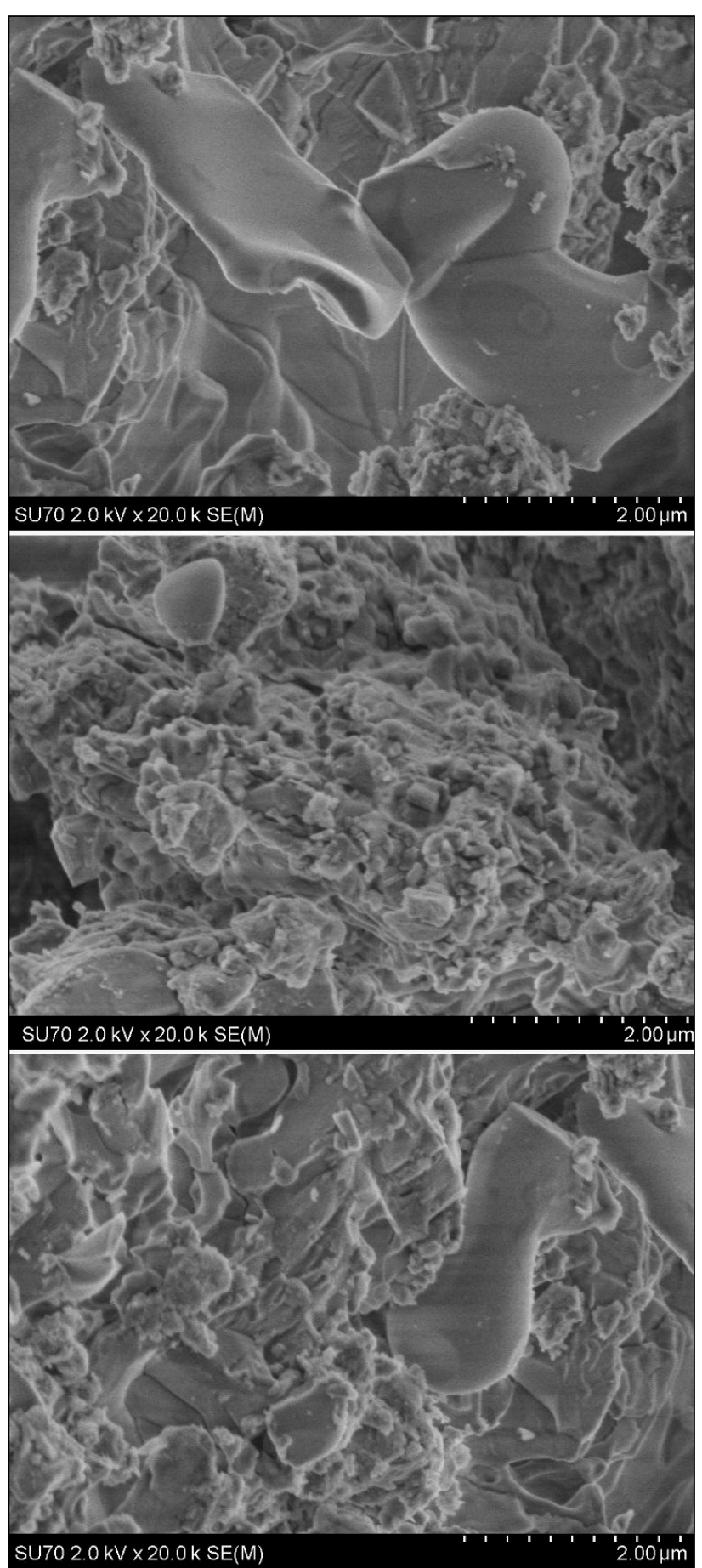

Fig. 3. SEM micrographs of the adipose tissue obtained from preperitoneal layers of obese patients with different metabolic diseases

can be seen from Fig. 1 that the adipose tissue samples are composed of cubes, prisms and spherically shaped granule particles less than $0.5 \mu \mathrm{m}$ in size. These different geometric shapes are connected by a solid matrix. Moreover, pores and voids can also be seen, which result probably from the different natural condition of the adipose tissue. The interesting morphological feature is rarely observed bright spots in all SEM micrographs of the SAT adipose tissue picked up from different patients. These bright spots are probably associated with metabolic changes in the body of obese patients. However, only few samples contain rod-and/or sticklike individual particles $0.5-2.0 \mu \mathrm{m}$ in size which were seen in the SEM images of SAT layers of healthy volunteers.

The SEM micrographs of the visceral adipose tissue revealed an individual surface morphology of the adipose tissue samples taken from different patients. Figure 5 shows the representative SEM micrographs of the VAT layer of the adipose tissue samples taken from the obese patients having different metabolic diseases. Interestingly, the individuality of morphology of different VAT adipose tissue samples is strongly expressed. One part of the samples are composed of large particles necked to each other. These single cloudy particles are usually covered with randomly distributed differently shaped nanoparticles. The second part of SEM micrographs could be attributed to the adipose tissue samples showing the network of multishaped nanoparticles $(50-100 \mathrm{~nm})$ distributed on the surface of hard agglomerates of plate-like microparticles $(0.3-0.5 \mu \mathrm{m})$. The surface of the third part of the samples instead of a continuous network is composed of separate spherical clusters $\sim 1.0-1.5 \mu \mathrm{m}$ in size. In some cases, these spherical clusters are prolonged in one direction and form dimeric or oligomeric fragments. Thus, careful morphological observations revealed that the surface of the visceral adipose tissue could serve very important biomedical information.

The SEM investigations are often used in conjunction with spot probe analyses by either EDX or WDX methods. It is known that a certain amount of different metals accumulated in the blood plasma or other human internal organs could be a signal of the seriousness and depth of the disease [33-36]. Therefore, we have evaluated the chemical composition of the adipose tissue samples by energy dispersive $\mathrm{X}$-ray spectroscopy in two scanning electron microscope. It was determined that the concentration of sodium and potassium in adipose layers is much higher in comparison with other elements. The concentration of magnesium is higher than that of calcium almost in all samples. Moreover, $\mathrm{Mn}$ and $\mathrm{Ni}$ were not detected in all analysed samples of the adipose tissue. The results of the EDX analysis obtained for the determination of selected transition elements in the PAT, SAT and VAT layers of the adipose tissue specimens are summarized in the Table. As seen, the concentrations of $\mathrm{Fe}$ and $\mathrm{Zn}$ do not vary significantly in the adipose tissue samples from different patients. However, the amount of iron was highest in the PAT layers, and the VAT layers generally contained a slightly smaller amount of Fe in comparison with the SAT layers. On the other hand, the random distribution of zinc in different layers of the adipose tissue was determined. Evidently, some adipose tissue samples contain a significantly higher amount of copper. Interestingly, a higher amount of copper is prevailing in the VAT layer. Also, a rather large amount of $\mathrm{Cu}$ was also determined in some samples of the SAT layer. Chromium was found only in the adipose of few patients. The relative standard 


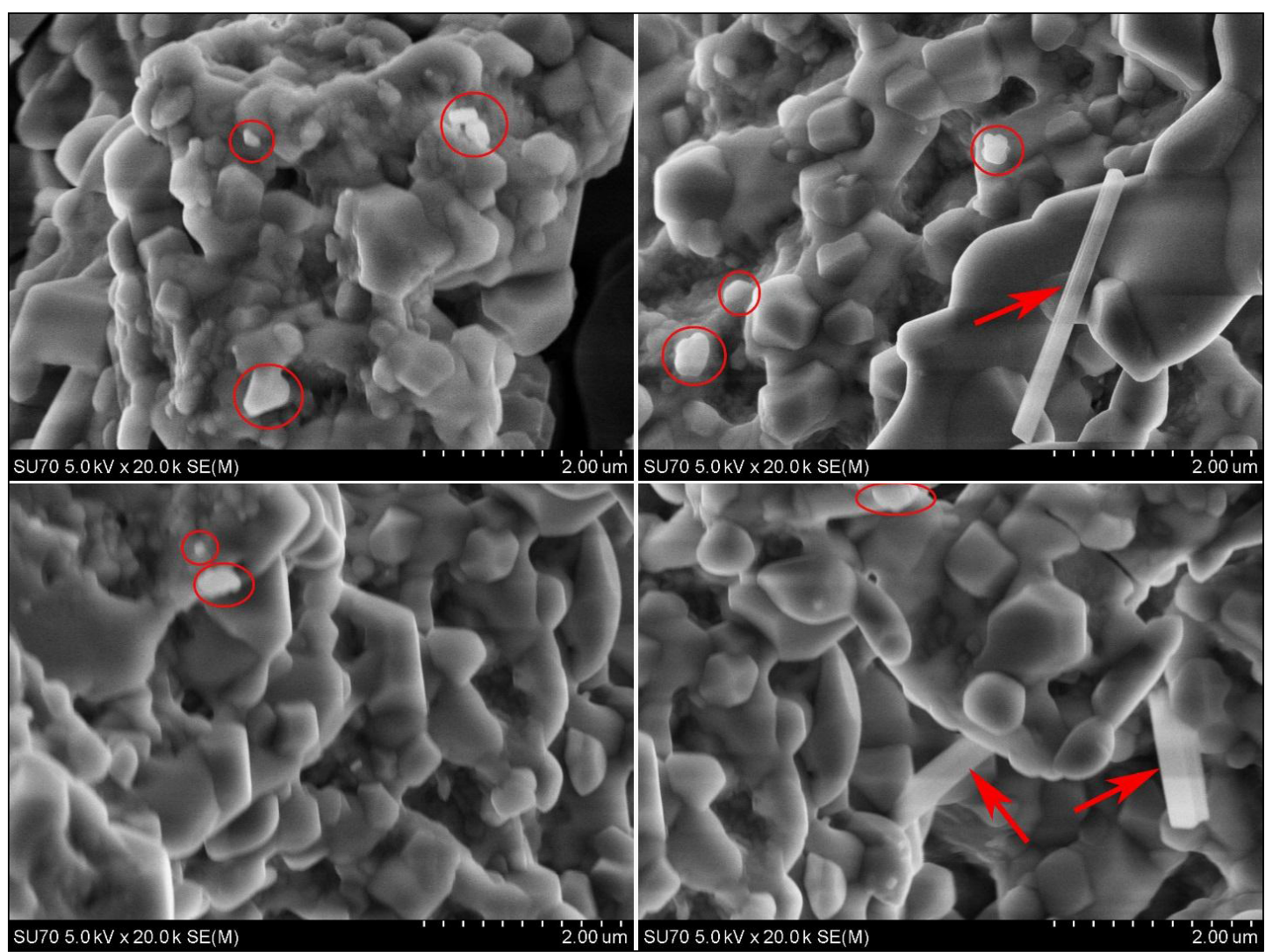

Fig. 4. SEM micrographs of the adipose tissue obtained from the subcutaneous layers of obese patients with different metabolic diseases. The bright spots are marked*

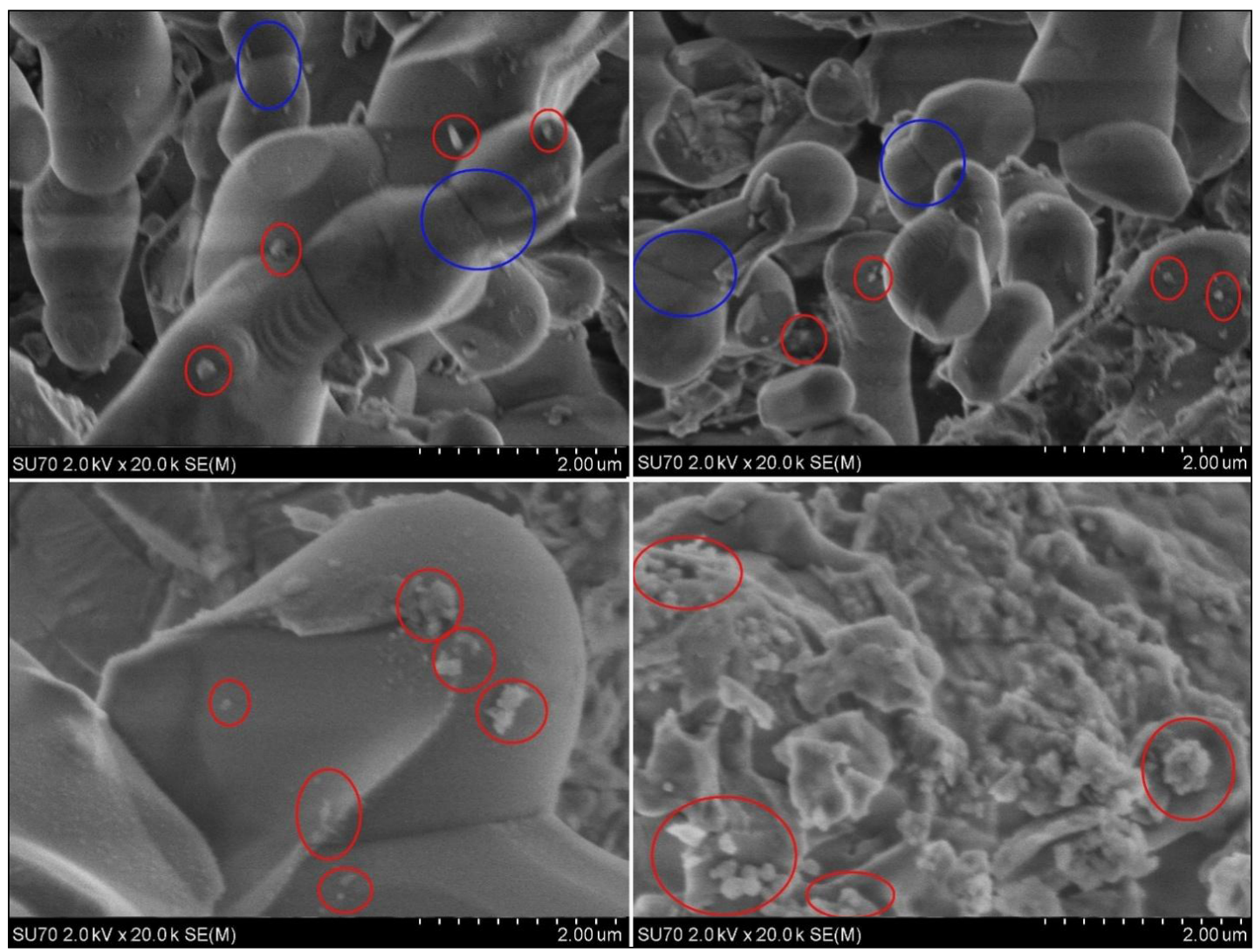

Fig. 5. SEM micrographs of the adipose tissue obtained from the visceral layers of obese patients with different metabolic diseases 
Table. Results of the EDX analysis for the determination of the average amount of transition metals in the subcutaneous (SAT), preperitoneal (PAT) and visceral (VAT) adipose tissue from obese patients $(n=3)$

\begin{tabular}{|c|c|c|c|c|c|c|c|}
\hline Sample & Metal & Layer & Amount, $\mu \mathrm{g} / \mathrm{g}$ & Layer & Amount, $\mu g / g$ & Layer & Amount, $\mu \mathrm{g} / \mathrm{g}$ \\
\hline \multirow{4}{*}{1} & $\mathrm{Fe}$ & \multirow{16}{*}{ SAT } & 29.1 & \multirow{16}{*}{ PAT } & 40.6 & \multirow{16}{*}{ VAT } & 17.7 \\
\hline & $\mathrm{Zn}$ & & 2.7 & & 3.0 & & 2.4 \\
\hline & $\mathrm{Cu}$ & & 0.2 & & 0.1 & & 0.5 \\
\hline & $\mathrm{Cr}$ & & - & & - & & - \\
\hline \multirow{4}{*}{2} & $\mathrm{Fe}$ & & 22.4 & & 23.2 & & 19.8 \\
\hline & $\mathrm{Zn}$ & & 5.1 & & 2.3 & & 2.1 \\
\hline & $\mathrm{Cu}$ & & 0.5 & & - & & 1.1 \\
\hline & $\mathrm{Cr}$ & & 3.7 & & - & & 1.8 \\
\hline \multirow{4}{*}{3} & $\mathrm{Fe}$ & & 27.9 & & 59.1 & & 17.8 \\
\hline & $\mathrm{Zn}$ & & 4.5 & & 3.7 & & 3.0 \\
\hline & $\mathrm{Cu}$ & & 0.2 & & 0.2 & & 0.6 \\
\hline & $\mathrm{Cr}$ & & 2.5 & & - & & - \\
\hline \multirow{4}{*}{4} & $\mathrm{Fe}$ & & 25.8 & & 36.2 & & 23.3 \\
\hline & $\mathrm{Zn}$ & & 4.2 & & 2.6 & & 3.9 \\
\hline & $\mathrm{Cu}$ & & 0.4 & & 0.1 & & 2.4 \\
\hline & $\mathrm{Cr}$ & & - & & - & & - \\
\hline \multirow{4}{*}{5} & $\mathrm{Fe}$ & \multirow{20}{*}{ SAT } & 32.1 & \multirow{20}{*}{ PAT } & 42.7 & \multirow{20}{*}{ VAT } & 20.0 \\
\hline & $\mathrm{Zn}$ & & 2.2 & & 3.8 & & 3.4 \\
\hline & $\mathrm{Cu}$ & & 0.3 & & - & & 0.9 \\
\hline & $\mathrm{Cr}$ & & - & & - & & - \\
\hline \multirow{4}{*}{6} & $\mathrm{Fe}$ & & 27.9 & & 36.7 & & 16.8 \\
\hline & $\mathrm{Zn}$ & & 2.5 & & 2.7 & & 4.0 \\
\hline & $\mathrm{Cu}$ & & 0.4 & & 0.2 & & 1.8 \\
\hline & $\mathrm{Cr}$ & & 4.1 & & 2.1 & & 5.5 \\
\hline \multirow{4}{*}{7} & $\mathrm{Fe}$ & & 21.8 & & 26.9 & & 15.9 \\
\hline & $\mathrm{Zn}$ & & 1.9 & & 2.8 & & 4.1 \\
\hline & $\mathrm{Cu}$ & & 0.4 & & 0.2 & & 2.6 \\
\hline & $\mathrm{Cr}$ & & - & & - & & 1.7 \\
\hline \multirow{4}{*}{8} & $\mathrm{Fe}$ & & 22.1 & & 39.4 & & 17.1 \\
\hline & $\mathrm{Zn}$ & & 2.6 & & 4.0 & & 3.6 \\
\hline & $\mathrm{Cu}$ & & 0.1 & & - & & 4.6 \\
\hline & $\mathrm{Cr}$ & & 2.4 & & 0.1 & & - \\
\hline \multirow{4}{*}{9} & $\mathrm{Fe}$ & & 22.1 & & 49.5 & & 22.1 \\
\hline & $\mathrm{Zn}$ & & 2.8 & & 2.8 & & 2.3 \\
\hline & $\mathrm{Cu}$ & & - & & - & & 0.8 \\
\hline & $\mathrm{Cr}$ & & 22.1 & & - & & 1.1 \\
\hline
\end{tabular}


Table (continued)

\begin{tabular}{|c|c|c|c|c|c|c|c|}
\hline Sample & Metal & Layer & Amount, $\mu \mathrm{g} / \mathrm{g}$ & Layer & Amount, $\mu \mathrm{g} / \mathrm{g}$ & Layer & Amount, $\mu \mathrm{g} / \mathrm{g}$ \\
\hline \multirow{4}{*}{10} & $\mathrm{Fe}$ & \multirow{20}{*}{ SAT } & 31.8 & \multirow{20}{*}{ PAT } & 46.8 & \multirow{20}{*}{ VAT } & 20.6 \\
\hline & $\mathrm{Zn}$ & & 3.7 & & 2.8 & & 2.1 \\
\hline & $\mathrm{Cu}$ & & 0.7 & & 0.1 & & 3.2 \\
\hline & $\mathrm{Cr}$ & & 0.3 & & - & & 4.6 \\
\hline \multirow{4}{*}{11} & $\mathrm{Fe}$ & & 32.7 & & 38.8 & & 18.2 \\
\hline & $\mathrm{Zn}$ & & 3.6 & & 4.8 & & 5.2 \\
\hline & $\mathrm{Cu}$ & & 0.7 & & - & & 6.6 \\
\hline & $\mathrm{Cr}$ & & - & & - & & - \\
\hline \multirow{4}{*}{12} & $\mathrm{Fe}$ & & 30.0 & & 49.1 & & 15.9 \\
\hline & $\mathrm{Zn}$ & & 3.3 & & 3.7 & & 5.0 \\
\hline & $\mathrm{Cu}$ & & 0.5 & & 0.3 & & 2.6 \\
\hline & $\mathrm{Cr}$ & & - & & - & & - \\
\hline \multirow{4}{*}{13} & $\mathrm{Fe}$ & & 26.8 & & 55.0 & & 19.5 \\
\hline & $\mathrm{Zn}$ & & 1.6 & & 2.5 & & 4.4 \\
\hline & $\mathrm{Cu}$ & & 1.4 & & 0.2 & & 4.4 \\
\hline & $\mathrm{Cr}$ & & - & & - & & - \\
\hline \multirow{4}{*}{14} & $\mathrm{Fe}$ & & 23.3 & & 37.1 & & 18.8 \\
\hline & $\mathrm{Zn}$ & & 5.1 & & 4.1 & & 1.2 \\
\hline & $\mathrm{Cu}$ & & 0.2 & & - & & 0.7 \\
\hline & $\mathrm{Cr}$ & & 4.0 & & 2.0 & & - \\
\hline \multirow{4}{*}{15} & $\mathrm{Fe}$ & \multirow{20}{*}{ SAT } & 23.9 & \multirow{20}{*}{ PAT } & 29.4 & \multirow{20}{*}{ VAT } & 16.9 \\
\hline & $\mathrm{Zn}$ & & 3.5 & & 3.0 & & 4.7 \\
\hline & $\mathrm{Cu}$ & & 0.1 & & 0.1 & & 1.3 \\
\hline & $\mathrm{Cr}$ & & 2.6 & & - & & 1.1 \\
\hline \multirow{4}{*}{16} & $\mathrm{Fe}$ & & 23.8 & & 29.6 & & 21.1 \\
\hline & $\mathrm{Zn}$ & & 2.1 & & 3.6 & & 3.0 \\
\hline & $\mathrm{Cu}$ & & 0.4 & & - & & 2.5 \\
\hline & $\mathrm{Cr}$ & & - & & - & & - \\
\hline \multirow{4}{*}{17} & $\mathrm{Fe}$ & & 27.7 & & 41.4 & & 22.3 \\
\hline & $\mathrm{Zn}$ & & 3.4 & & 4.0 & & 3.7 \\
\hline & $\mathrm{Cu}$ & & 0.8 & & 0.3 & & 2.9 \\
\hline & $\mathrm{Cr}$ & & 0.8 & & - & & 3.5 \\
\hline \multirow{4}{*}{18} & $\mathrm{Fe}$ & & 27.1 & & 54.7 & & 17.3 \\
\hline & $\mathrm{Zn}$ & & 3.5 & & 4.9 & & 2.8 \\
\hline & $\mathrm{Cu}$ & & 0.3 & & 0.1 & & 3.5 \\
\hline & $\mathrm{Cr}$ & & - & & - & & - \\
\hline \multirow{4}{*}{19} & $\mathrm{Fe}$ & & 31.2 & & 27.6 & & 20.5 \\
\hline & $\mathrm{Zn}$ & & 3.1 & & 1.5 & & 2.1 \\
\hline & $\mathrm{Cu}$ & & 2.0 & & 0.5 & & 2.9 \\
\hline & $\mathrm{Cr}$ & & - & & - & & 5.5 \\
\hline
\end{tabular}


Table (continued)

\begin{tabular}{|c|c|c|c|c|c|c|c|}
\hline Sample & Metal & Layer & Amount, $\mu \mathrm{g} / \mathrm{g}$ & Layer & Amount, $\mu \mathrm{g} / \mathrm{g}$ & Layer & Amount, $\mu \mathrm{g} / \mathrm{g}$ \\
\hline \multirow{4}{*}{20} & $\mathrm{Fe}$ & \multirow{20}{*}{ SAT } & 24.7 & \multirow{20}{*}{ PAT } & 39.9 & \multirow{20}{*}{ VAT } & 19.0 \\
\hline & $\mathrm{Zn}$ & & 4.8 & & 4.5 & & 3.9 \\
\hline & $\mathrm{Cu}$ & & 2.2 & & 0.4 & & 4.1 \\
\hline & $\mathrm{Cr}$ & & - & & - & & - \\
\hline \multirow{4}{*}{21} & $\mathrm{Fe}$ & & 24.9 & & 33.3 & & 19.9 \\
\hline & $\mathrm{Zn}$ & & 3.0 & & 3.3 & & 3.3 \\
\hline & $\mathrm{Cu}$ & & 3.2 & & 0.2 & & 6.2 \\
\hline & $\mathrm{Cr}$ & & - & & - & & - \\
\hline \multirow{4}{*}{22} & $\mathrm{Fe}$ & & 24.8 & & 35.2 & & 20.2 \\
\hline & $\mathrm{Zn}$ & & 0.7 & & 0.2 & & 2.9 \\
\hline & $\mathrm{Cu}$ & & 0.42 & & 0.52 & & 2.44 \\
\hline & $\mathrm{Cr}$ & & - & & - & & - \\
\hline \multirow{4}{*}{23} & $\mathrm{Fe}$ & & 20.9 & & 42.6 & & 21.1 \\
\hline & $\mathrm{Zn}$ & & 3.6 & & 3.8 & & 2.9 \\
\hline & $\mathrm{Cu}$ & & - & & - & & 3.0 \\
\hline & $\mathrm{Cr}$ & & - & & - & & - \\
\hline \multirow{4}{*}{24} & $\mathrm{Fe}$ & & 28.9 & & 28.0 & & 18.6 \\
\hline & $\mathrm{Zn}$ & & 4.4 & & 2.4 & & 4.1 \\
\hline & $\mathrm{Cu}$ & & 0.3 & & 0.3 & & 4.2 \\
\hline & $\mathrm{Cr}$ & & 0.1 & & - & & - \\
\hline \multirow{4}{*}{25} & $\mathrm{Fe}$ & \multirow{20}{*}{ SAT } & 30.6 & \multirow{20}{*}{ PAT } & 36.0 & \multirow{20}{*}{ VAT } & 14.6 \\
\hline & $\mathrm{Zn}$ & & 3.4 & & 2.8 & & 5.1 \\
\hline & $\mathrm{Cu}$ & & 2.4 & & 0.5 & & 5.0 \\
\hline & $\mathrm{Cr}$ & & - & & - & & 1.7 \\
\hline \multirow{4}{*}{26} & $\mathrm{Fe}$ & & 27.5 & & 37.6 & & 18.4 \\
\hline & $\mathrm{Zn}$ & & 5.4 & & 4.4 & & 4.2 \\
\hline & $\mathrm{Cu}$ & & 2.6 & & 0.5 & & 5.6 \\
\hline & $\mathrm{Cr}$ & & - & & - & & 5.3 \\
\hline \multirow{4}{*}{27} & $\mathrm{Fe}$ & & 25.5 & & 46.6 & & 17.0 \\
\hline & $\mathrm{Zn}$ & & 4.5 & & 5.7 & & 2.6 \\
\hline & $\mathrm{Cu}$ & & 3.3 & & - & & 4.5 \\
\hline & $\mathrm{Cr}$ & & - & & - & & - \\
\hline \multirow{4}{*}{28} & $\mathrm{Fe}$ & & 25.1 & & 39.6 & & 15.3 \\
\hline & $\mathrm{Zn}$ & & 5.2 & & 4.6 & & 5.3 \\
\hline & $\mathrm{Cu}$ & & - & & - & & 8.7 \\
\hline & $\mathrm{Cr}$ & & 0.3 & & 0.2 & & 0.3 \\
\hline \multirow{4}{*}{29} & $\mathrm{Fe}$ & & 22.3 & & 52.2 & & 14.7 \\
\hline & $\mathrm{Zn}$ & & 3.7 & & 1.9 & & 1.8 \\
\hline & $\mathrm{Cu}$ & & 0.6 & & 0.1 & & 9.5 \\
\hline & $\mathrm{Cr}$ & & - & & - & & - \\
\hline
\end{tabular}


Table (continued)

\begin{tabular}{|c|c|c|c|c|c|c|c|}
\hline Sample & Metal & Layer & Amount, $\mu \mathrm{g} / \mathrm{g}$ & Layer & Amount, $\mu \mathrm{g} / \mathrm{g}$ & Layer & Amount, $\mu \mathrm{g} / \mathrm{g}$ \\
\hline \multirow{4}{*}{30} & $\mathrm{Fe}$ & \multirow{24}{*}{ SAT } & 31.1 & \multirow{24}{*}{ PAT } & 57.3 & \multirow{24}{*}{ VAT } & 22.2 \\
\hline & $\mathrm{Zn}$ & & 3.5 & & 2.6 & & 4.2 \\
\hline & $\mathrm{Cu}$ & & 0.5 & & 0.2 & & 0.6 \\
\hline & $\mathrm{Cr}$ & & - & & - & & - \\
\hline \multirow{4}{*}{31} & $\mathrm{Fe}$ & & 23.3 & & 25.8 & & 20.1 \\
\hline & $\mathrm{Zn}$ & & 4.5 & & 4.7 & & 5.0 \\
\hline & $\mathrm{Cu}$ & & 2.1 & & 0.4 & & 4.4 \\
\hline & $\mathrm{Cr}$ & & 0.9 & & - & & - \\
\hline \multirow{4}{*}{32} & $\mathrm{Fe}$ & & 26.8 & & 29.9 & & 20.4 \\
\hline & $\mathrm{Zn}$ & & 3.1 & & 2.9 & & 5.1 \\
\hline & $\mathrm{Cu}$ & & 0.9 & & 0.1 & & 3.1 \\
\hline & $\mathrm{Cr}$ & & 0.2 & & - & & 2.7 \\
\hline \multirow{8}{*}{34} & $\mathrm{Fe}$ & & 24.6 & & 49.2 & & 14.5 \\
\hline & $\mathrm{Zn}$ & & 4.0 & & 2.8 & & 5.0 \\
\hline & $\mathrm{Cu}$ & & 0.9 & & 0.6 & & 7.6 \\
\hline & $\mathrm{Cr}$ & & - & & - & & - \\
\hline & $\mathrm{Fe}$ & & 26.6 & & 50.0 & & 15.4 \\
\hline & $\mathrm{Zn}$ & & 1.5 & & 4.7 & & 3.2 \\
\hline & $\mathrm{Cu}$ & & 0.8 & & 0.2 & & 1.0 \\
\hline & $\mathrm{Cr}$ & & 1.55 & & - & & - \\
\hline \multirow{4}{*}{35} & $\mathrm{Fe}$ & & 31.6 & & 41.5 & & 20.2 \\
\hline & $\mathrm{Zn}$ & & 4.0 & & 3.1 & & 3.9 \\
\hline & $\mathrm{Cu}$ & & 0.4 & & - & & 5.3 \\
\hline & $\mathrm{Cr}$ & & 1.0 & & - & & 2.3 \\
\hline
\end{tabular}

deviation (RSD) values obtained for the determination of metals in the adipose from the obese patients (3.4-7.1\%) indicate a high degree of homogeneity, which could be expected for adipose samples. Moreover, the values obtained are not unusual for such type of analysis and can be considered as suitable for a routine analysis. No doubt, the results of the elemental analysis obtained show various distributions of different metals in the adipose tissue of patients with a different metabolical state. We may assume, however, that the results of copper and chromium distribution in adipose tissue layers in obese patients are promising for further medical observation. The change in concentrations of these metals in the adipose tissue might be the sign or the possible reason for appearance of symptoms of different diseases. Finally, the initial observations show such a tendency that a higher concentration of metals prevail in SAT and VAT layers. However, the distribution of metal levels in adipose tissue layers is rather chaotic and important information could be probably obtained after a more intensive study.

The secondary electrons are emitted by atoms near the surface of a sample material when their electrons become excited and have sufficient energy to escape the sam- ple surface. Consequently, secondary electron imaging, being more surface sensitive, has a greater resolution. The escape depth of backscattered electrons can be greater than that of secondary electrons, consequently resolution of surface topographical characteristics can suffer. However, from the backscattered electron SEM images it is possible to obtain information on the sample composition. Moreover, backscattered electrons have the advantage that they are sensitive to the atomic mass of the nuclei they scatter from. As a result, heavier elements which backscatter more efficiently appear brighter than lighter elements in a backscattered electron image. Thus, a "brighter" BSE intensity correlates with greater average $\mathrm{Z}$ in the sample, and "dark" areas have lower average Z. BSE images are very helpful for obtaining high-resolution compositional maps of a sample and for quickly distinguishing different phases [37. The representative BSE SEM micrographs of adipose samples from the PAT layer containing different concentration of iron are shown in Fig. 6. As seen, lighter areas corresponding to accumulation of iron are denser, and darker areas are less. Since Sample 3 contains a higher amount of iron, dense lighter areas are more pronounced in the corresponding SEM BSE image. This is generally true in all 


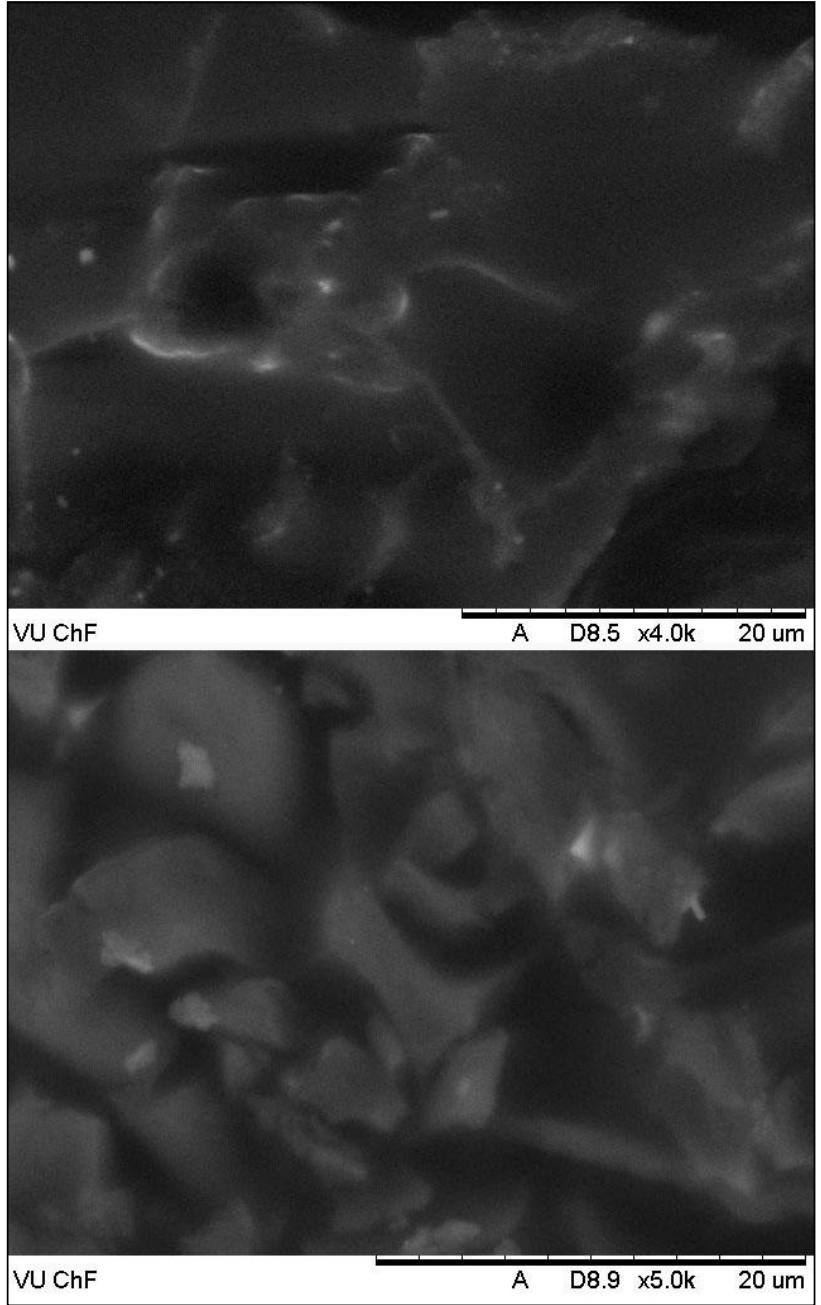

Fig. 6. SEM BSE micrographs of the adipose tissue obtained from the preperitoneal layers of obese patients with different metabolic diseases: Sample 3 (bottom) and Sample 15 (top). The samples contain a different concentration of Fe

images of the PAT adipose tissue samples. The iron parts are bright while the carbon ones containing fats are featureless. Not even the dimples and pores in the total area are evident.

The second combination of SEM BSE images is shown in Fig. 9. The micrographs are obtained at the back-scattering mode for the SAT samples with a different amount of chromium. However, one must be very careful in interpreting such images. Evidently, the bright spots are intensively distributed in the micrographs of the samples containing chromium from 4.1 to $6.2 \mu \mathrm{g} / \mathrm{g}$. But the planar grey parts are also involved in a rather big part of images. Interestingly, the lighter areas corresponding to accumulation, probably, of iron could be detected in the micrograph of the SAT sample without any traces of chromium. The depth of imaging with backscattered electrons in the scanning electron microscope, probably, should be measured to achieve a better interpretation of the obtained results [37]. Figure 8 shows three representative SEM BSE micrographs of the VAT layer of the adipose tissue samples having a very similar amount of chromium (5.3-5.5 $\mu \mathrm{g} / \mathrm{g})$ and taken from obese pa-
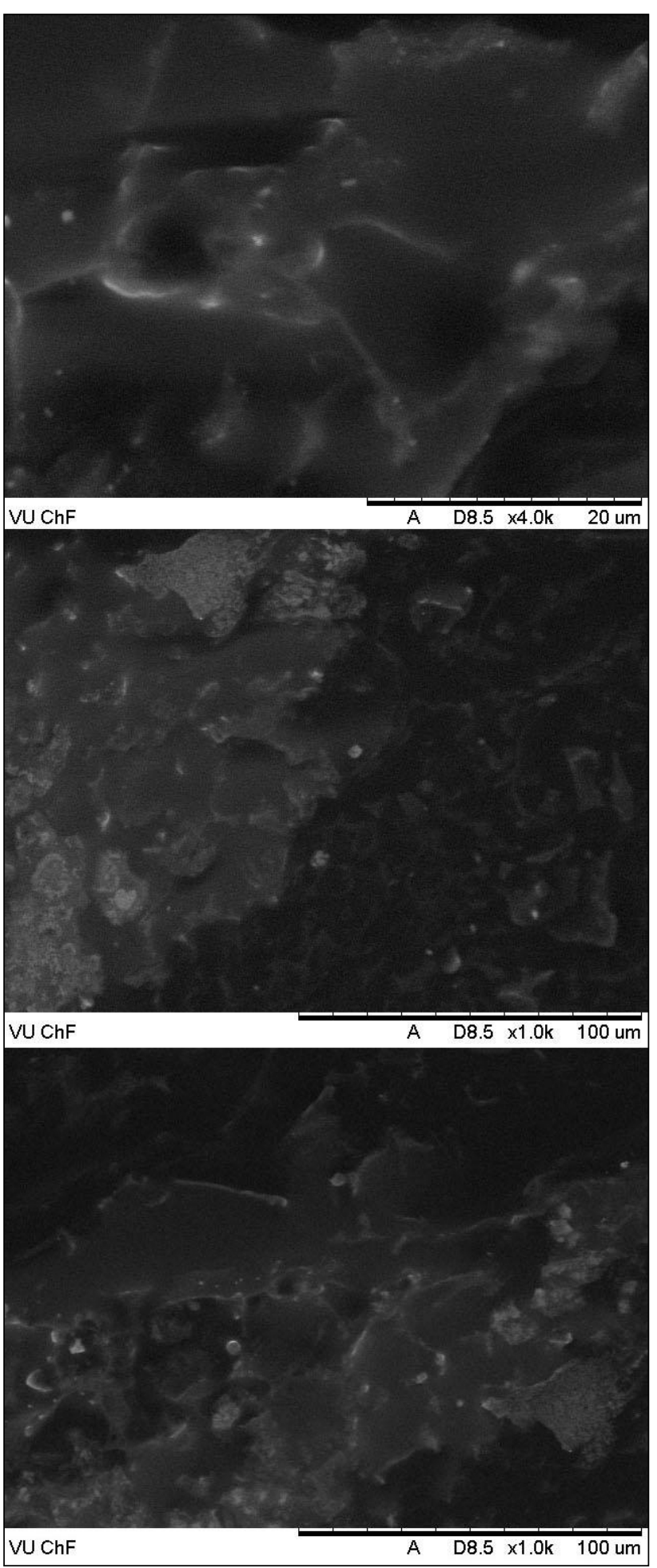

Fig. 7. SEM BSE micrographs of the adipose tissue obtained from subcutaneous layers of obese patients with different metabolic diseases: Sample 9 (bottom), Sample 6 (middle) and Sample 30 (top). The samples contain a different amount of chromium

tients having different metabolic diseases. Interestingly, there are no significant differences evidenced in the surface morphology and elemental content between these samples. However, the concentration and distribution of bright, grey and dark areas in the micrographs is obvious. The BSE 


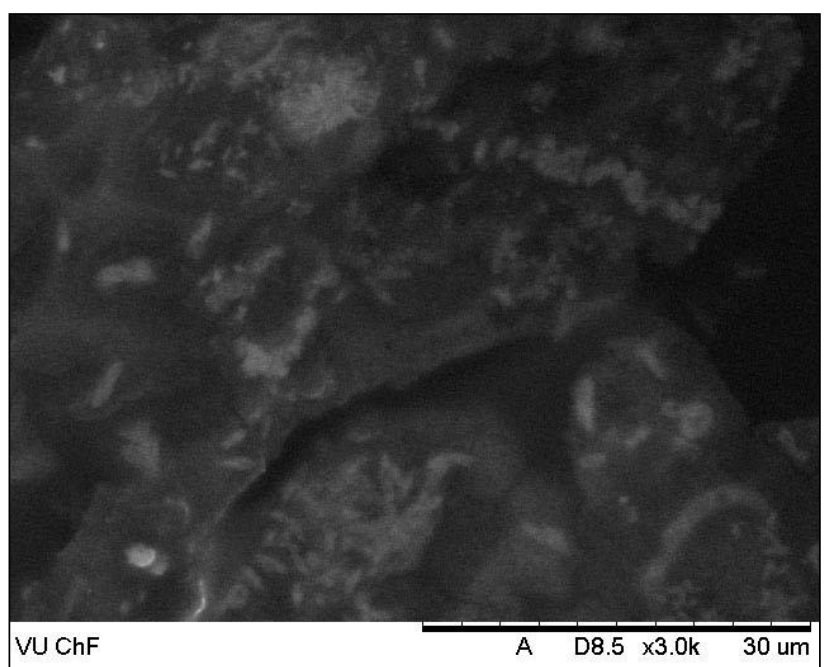

tensive that even its detection is problematic. A quite different situation could be observed in the BSE image of the 26 VAT sample. The continuous network of a grey part is homogeneously "spin-coated" with white matter with a good connectivity. Moreover, the dark area is almost missing in this SEM BSE micrograph. The contrast of backscattered electron images in scanning electron microscopy depends on material parameters which can be exploited for composition quantification if some information on the material system is available [38]. The image intensity can be evaluated to determine the composition and local thickness of the specimen. Evidently, these results should be statistically analysed using any selected statistical test [39].

The biphasic character of the investigated fat samples containing copper is evident from the SEM measurements.

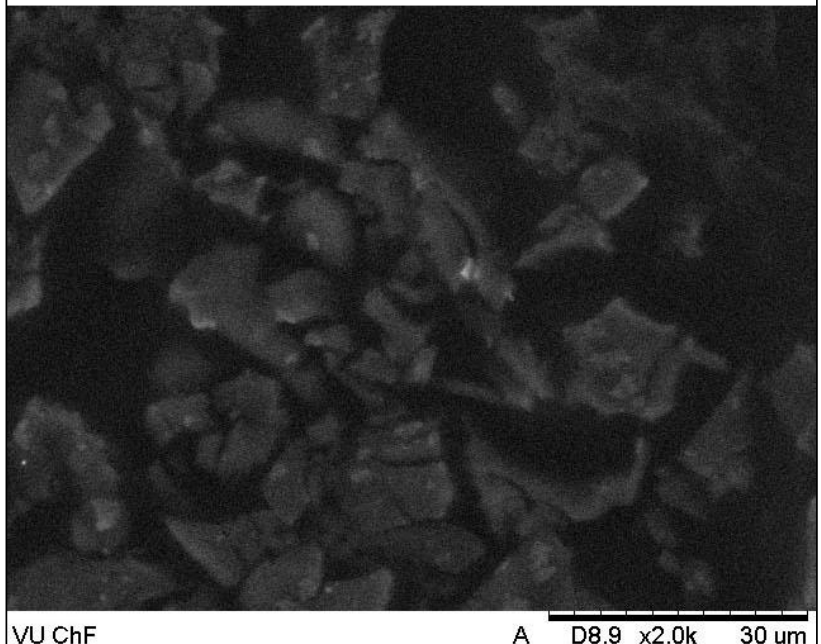
The representative BSE SEM micrographs of the VAT adipose tissue sample containing the highest amount of $\mathrm{Cu}$ $(9.5 \mu \mathrm{g} / \mathrm{g})$ are shown in Fig. 9. The images showed an increase of the formation of light spots on visceral adipose

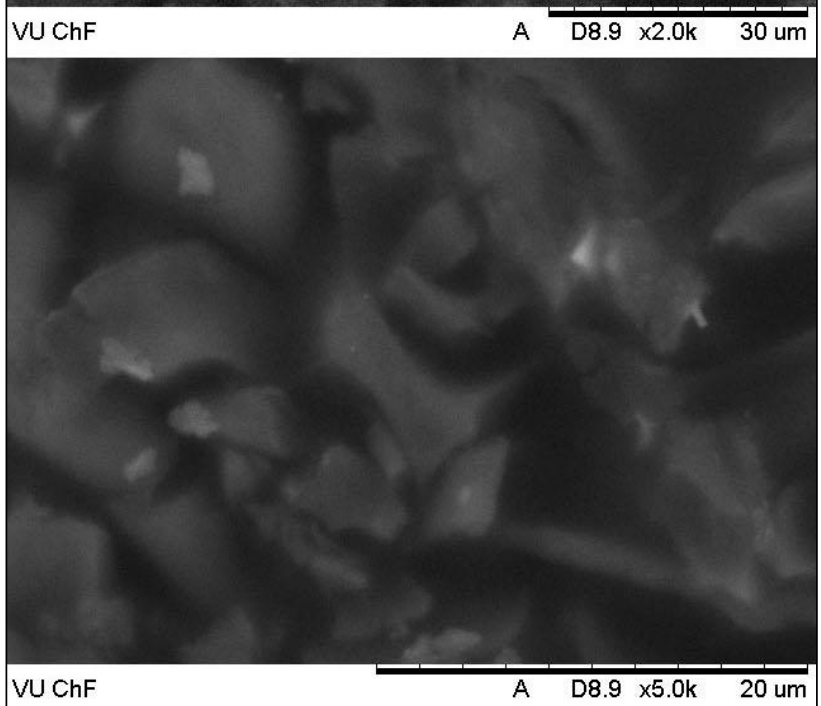

Fig. 8. SEM BSE micrographs of the adipose tissue obtained from visceral layers of obese patients with different metabolic diseases: Sample 6 (bottom), Sample 19 (middle) and Sample 26 (top). The samples contain a different amount of chromium

image of the VAT layer of Sample 6 is mostly composed of grey voluminous plates randomly covered by white spots. The smaller grey parts are more connected to each other for the VAT Sample 19. The distribution of bright spots is so in-

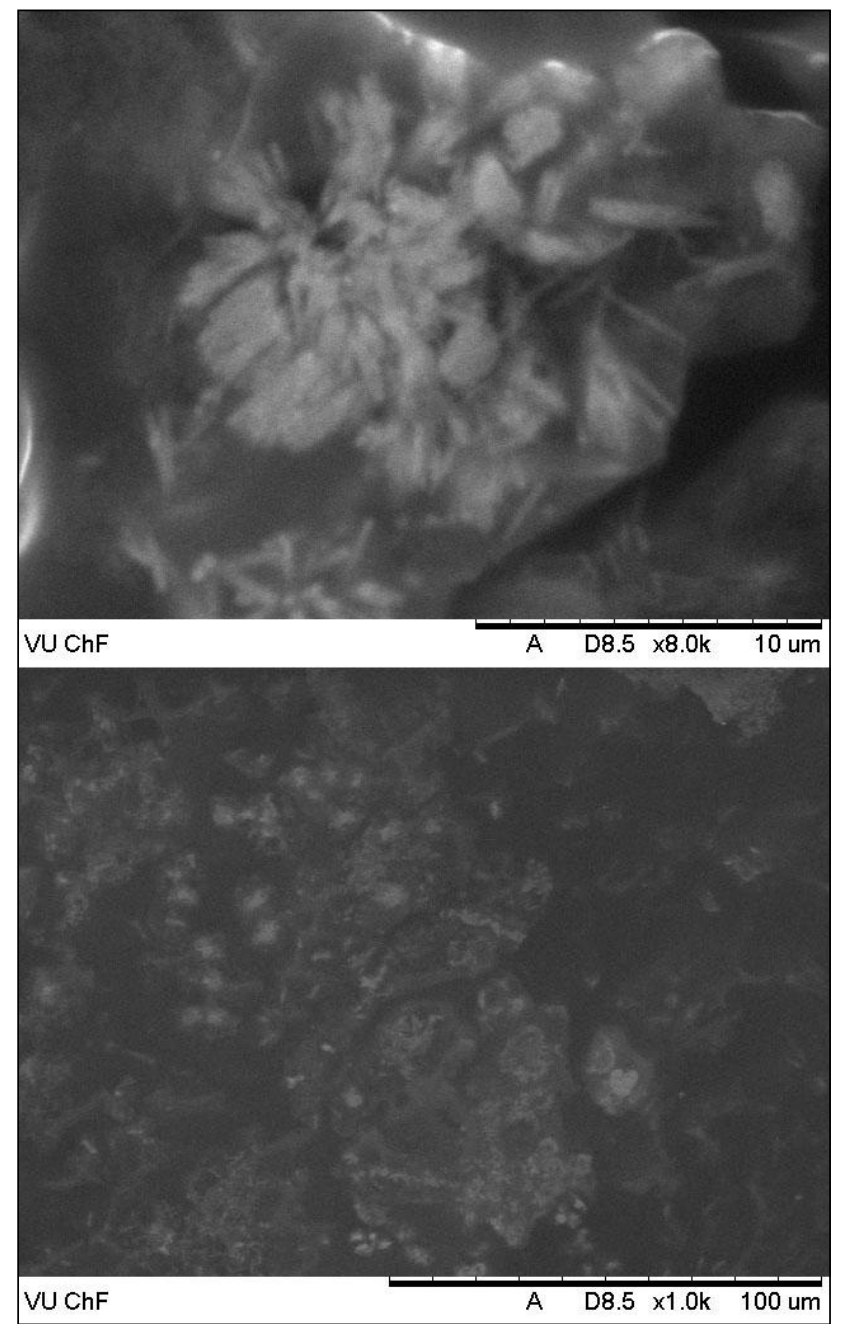

Fig. 9. SEM BSE micrographs at different magnifications of adipose tissue Sample 29 obtained from the visceral layers of the obese patient with metabolic disease. The sample contains the highest amount of $\mathrm{Cu}$ 
tissues. Within the limits of this study, the short period was not enough to detect differences in clinical parameters among different adipose tissues. Clinical and radiographic analyses are under investigation. Besides, a newly developed scanning electron microscopy method to obtain 3D structural information could be also employed to provide a deeper insight in the morphology of these materials [40-42].

\section{CONCLUSIONS}

We demonstrated for the first time, to the best of our knowledge, the application of scanning electron microscopy (SEM) and metal content determination by energy dispersive X-ray spectroscopy (EDX) in a scanning electron microscope for the characterization of the adipose tissue from obese patients. The fat samples were taken from the subcutaneous (SAT), preperitoneal (PAT) and visceral (VAT) layers of the adipose tissue. The SEM micrographs of samples from the PAT layer of the adipose tissue showed that the adipose tissue of the preperitoneal layer is composed of irregularly shaped particles $200 \mathrm{~nm}-2 \mu \mathrm{m}$ in size which are closely connected to each other forming hard agglomerates. The microstructure of the adipose tissue PAT layers obtained from different patients is quite similar. The SEM micrographs of the subcutaneous adipose tissue layer taken from obese patients having different metabolic diseases were slightly different in comparison with the ones taken from the SAT layers of people without metabolic diseases. The adipose tissue samples were composed of cubes, prisms and spherically shaped granule particles less than $0.5 \mu \mathrm{m}$ in size. The interesting morphological feature was rarely observed bright spots in all SEM micrographs of the SAT adipose tissue picked up from different patients. The SEM micrographs of the visceral adipose tissue revealed the individual surface morphology of adipose tissue samples taken from different patients. These initial SEM observations let us to conclude that the preperitoneal layer could perhaps be considered as a passive organ, i.e. is not associated with metabolic changes in the human body. These bright spots seen in the SEM images of SAT layers are probably associated with metabolic changes in the body of obese patients. Moreover, careful morphological observations revealed that the surface of the visceral adipose tissue could serve as very important biomedical information. The results of the elemental analysis obtained showed various distributions of different metals in the adipose tissue of patients with a different metabolical state. However, the results of distribution of copper and chromium in adipose tissue layers in obese patients are promising for further medical observation. The morphological results obtained from the representative BSE SEM micrographs of adipose samples from SAT, PAT and VAT layers were in a good agreement with the analytical results. Obviously, further investigation is needed to prove the impact of chemical composition, structural and morphological features on adipose tissue activity and their relationship with a disease stage. Of course, medical conclusions could be made only after a careful and systematic investigation of numerous patients with obesity and different comorbidities.

\section{ACKNOWLEDGEMENTS}

This work was supported by the grant SEMAT (No. SEN02/2016) of the National Research Programme "Healthy Ageing" from the Research Council of Lithuania. The authors would like to thank A. Smalenskaite for the technical assistance.

Received 16 January 2018

Accepted 18 January 2018

\section{References}

1. V. Mohamed-Ali, J. H. Pinkney, S. W. Coppack, Int. J. Obes. Relat. Metab. Disord., 22, 1145 (1998).

2. L. P. Luo, M. L. Liu, J. Endocr., 231, R77 (2016).

3. K. G. Kahl, J. Herrmann, B. Stubbs, et al., Progr. NeuroPsychopharmacol. Biol. Psych., 72, 30 (2017).

4. T. Y. Kim, A. L. Schafer, Curr. Osteop. Rep., 14, 337 (2016).

5. M. A. Kasinska, J. Drzewoski, A. Sliwinska, Archiv. Med. Sci., 12, 1293 (2016).

6. A. Feola, S. Ricci, S. Kouidhi, et al., J. Cellul. Physiol., 232, 69 (2017)

7. D. H. Ipsen, P. Tveden-Nyborg, J. Lykkesfeldt, Curr. Obes. Rep., 5, 405 (2016).

8. J. P. Bastard, B. Feve, Physiology and Physiopathology of Adipose Tissue, Springer-Verlag, France (2013).

9. C. M. Ahlberg, L. N. Schiermiester, J. T. Howard, C. R. Calkins, M. L. Spangler, Meat Sci., 98, 804 (2014).

10. H. Q. Li, A. Chen, L. Shu, et al., Genes Cell., 19, 793 (2014).

11. K. Uebel, K. Pusch, K. Gedrich, K. T. M. Schneider, H. Hauner, B. L. Bader, BMC Pregnancy Childbirth, 14, Art. No. 138 (2014).

12. S. Casteras, A. Abdul-Wahed, M. Soty, et al., Diabetologia, 59, 2645 (2016).

13. M. Ebadi, V. E. Baracos, O. F. Bathe, L. E. Robinson, V. C. Mazurak, Clin. Nutrit., 35, 1347 (2016).

14. A. Selovic, J. Sarac, S. Missoni, J. Matern. Fetal Neonatal Med., 29, 2131 (2016).

15. B. Hacihamdioglu, G. Ocal, M. Berberoglu, et al., Ultrasound Med. Biol., 40, 871 (2014).

16. C. Pisitsak, J. G. H. Lee, J. H. Boyd, H. O. Coxson, J. A. Russell, K. R. Walley, Critic. Care Med., 44, 19663 (2016).

17. G. E. Shearrer, M. J. Daniels, C. M. Toledo-Corral, M. J. Weigensberg, D. Spruijt-Metz, J. N. Davis, Physiol. Behav., 167, 188 (2016).

18. S. J. Yu, W. Kim, D. Kim, et al., Medicine, 94, Art. No. e2159 (2015).

19. E. S. Wahyuni, I. W. A. Wiyasa, N. Nurdiana, Middle East Fertil. Soc. J., 21, 259 (2016).

20. M. Z. Zhang, T. Hu, S. Y. Zhang, L. Zhou, Sci. Rep., 5, Art. No. 18495 (2015). 
21. F. Bevalot, C. Bottinelli, N. Cartiser, L. Fanton, J. Guitton, J. Anal. Toxicol., 38, 256 (2014).

22. N. Quinete, T. Schettgen, J. Bertram, T. Kraus, Anal. Bioanal. Chem., 406, 6151 (2014).

23. R. Anlicoara, A. A. B. Ferraz, K. D. Coelho, et al., Obes. Surg., 24, 1487 (2014).

24. M. Guan, D. S. Dai, L. Li, et al., Talanta, 172, 206 (2017).

25. E. Bartosinska, J. Jacyna, A. Borsuk-De Moor, et al., Talanta, 176, 108 (2018).

26. M. Y. Bekhit, B. Grung, S. A. Mjos, Appl. Spectrosc., 68, 1190 (2014).

27. D. Lu, C. Feng, Y. Lin, et al., Chemosphere, 114, 327 (2014).

28. S. Vedantham, L. X. Shi, A. Karellas, Phys. Med. Biol., 59, 6387 (2014).

29. B. Buckus, G. Brimas, A. Stasinskas, et al., Chemija, 26, 98 (2015).

30. D. P. Lo Fiego, G. Minelli, L. A. Volpelli, A. Ulrici, P. Macchioni, Meat Sci., 122, 132 (2016).

31. P. Meksiarun, B. B. Andriana, H. Matsuyoshi, H. Sato, Sci. Rep., 6, Art. No. 37068 (2016).

32. I. Dagla, D. Benaki, E. Baira, et al., Talanta, 178, 246 (2018).

33. S. Tautkus, A. Irnius, D. Speiciene, J. Barkauskas, A. Kareiva, Ann. Chim., 97, 1139 (2007).

34. S. Brašiškiene, A. Irnius, E. Gavelienè, S. Tautkus, A. Kareiva, Chemija, 22, 223 (2011).

35. J. A. Roth, R. Salvi, Neurotox. Res., 30, 268 (2016).

36. M. Toni, M. L. Massimino, A. De Mario, E. Angiulli, E. Spisni, Front. Neurosci., 11, Art. No. 3 (2017).

37. J. Pinos, S. Mikmekova, L. Frank, J. Microsc., 266, 335 (2017).

38. E. Mueller, D. Gerthsen, Ultramicrosc., 173, 71 (2017).
39. S. Hersche, I. Sifakakis, S. Zinelis, T. Eliades, Biomed. Techn., 62, 97 (2017).

40. S. Kareiva, A. Selskis, F. Ivanauskas, S. Sakirzanovas, Pure Appl. Chem., 87, 283 (2015).

41. S. Kareiva, A. Selskis, F. Ivanauskas, S. Sakirzanovas, A. Kareiva, Mater. Sci. (Medžiagotyra), 21, 640 (2015).

42. S. Kareiva, V. Klimavicius, A. Momot, et al., J. Mol. Struct., 1119, 1 (2016).

Ramūnas Skaudžius, Martynas Misevičius, Vilma Brimienė, Margarita Beniušè, Gintautas Brimas, Aivaras Kareiva

\section{SEM (EDX) - BŪTINAS İRANKIS, SKIRTAS APIBŪDINTI NUTUKUSIŲ PACIENTŲ POODINI, PREPERITONINI IR VISCERALINI RIEBALINIUS AUDINIUS}

Santrauka

Šiame darbe skenuojanti elektroninė mikroskopija (SEM) ir energijos dispersinè rentgeno spindulių (EDX) elementinè analizė naudojamos apibūdinant riebalinio audinio mèginius, paimtus iš nutukusių pacientų. Riebalinis audinys buvo paimtas iš poodinio, preperitoninio ir visceralinio riebalinio audinio sluoksnių. Rezultatai leido apibūdinti žmogaus riebalinio audinio sluoksnių struktūrinius ypatumus, elementinę sudètí, taip pat pagrindines mikrostruktūrines savybes. Pirmą kartą (mūsų žiniomis) įrodyta, kad SEM ir EDX yra būtini ịrankiai siekiant ištirti kai kuriuos ypatingus žmogaus riebalinio audinio sluoksnių morfologinius ypatumus ir elementinę sudètį. Priejome prie išvados, kad toks riebalinio audinio apibūdinimas yra esminis žingsnis siekiant numatyti ịvairių ligų simptomus. 
